\title{
KERAGAAN, KERAGAMAN, DAN HERITABILITAS KARAKTER AGRONOMI KACANG PANJANG (Vigna Unguiculata) GENERASI F 1 HASIL PERSILANGAN TIGA GENOTIPE
}

\author{
Nyimas Sa'diyah, Maylinda Widiastuti \& Ardian \\ Jurusan Agroteknologi, Fakultas Pertanian Universitas Lampung \\ Jl.Prof. Soemantri Brodjonegoro, No.1, Bandar Lampung 35145 \\ E-mail: nyimas_diyah@yahoo.com
}

\begin{abstract}
ABSTRAK
Untuk meningkatkan produksi kacang panjang, perlu penggunaan varietas unggul. Perakitan varietas unggul dapat diperoleh melalui persilangan dua tetua yang memiliki perbedaan. Hasil persilangan antargenotipe kacang panjang dapat dilihat melalui keragaan yang ditampilkan pada generasi keturunan $\left(\mathrm{F}_{1}\right)$. Pada hasil persilangan antartetua yang berbeda dapat diharapkan terdapat keragaman antara hasil persilangan. Penelitian ini bertujuan untuk melihat keragaan karakter agronomi, keragaman dan nilai duga heritabilitas arti luas kacang panjang generasi $\mathrm{F}_{1}$ hasil persilangan tiga genotipe. Benih yang digunakan adalah benih $F_{1}$ kacang panjang yang merupakan hasil persilangan antara testa merah putih $\mathrm{x}$ testa hitam $(\mathrm{AxB})$, testa hitam $\mathrm{x}$ testa merah putih (BxA), testa hitam $x$ testa coklat $(\mathrm{BxC})$, testa coklat $\mathrm{x}$ testa merah putih $(\mathrm{CxA})$, benih tetua testa merah putih, testa hitam, testa coklat. Penelitian ini dilakukan dengan Rancangan Kelompok Teracak Sempurna (RKTS) dan data dianalisis dengan menggunakan, analisis ragam,dan dilanjutkan uji LSI (Least Significant Increase) . Hasil penelitian menunjukkan bahwa keragaman fenotipe karakter agronomi kacang panjang hasil persilangan tiga genotipe adalah luas untuk semua variabel. Untuk keragaman genotipe karakter agronomi kacang panjang hasil persilangan tiga genotipe adalah luas untuk variabel umur berbunga, umur panen polong kering, jumlah polong tanaman, rata-rata jumlah polong tanaman, rata-rata panjang lokul, jumlah benih total, bobot benih tanaman, tetapi untuk variabel umur panen polong segar, jumlah tangkai bunga, rata-rata panjang polong tanaman, rata-rata jumlah lokul tanaman dan bobot 100 benih adalah sempit. Besaran nilai heritabilitas arti luas karakter agronomi kacang panjang generasi $F_{1}$ hasil persilangan tiga genotipe. untuk variabel umur berbunga dan rata-rata panjang lokul adalah tinggi, variabel umur panen polong kering, jumlah polong tanaman, rata-rata jumlah polong tanaman, dan jumlah benih total adalah sedang, variabel umur panen polong segar, jumlah tangkai bunga, rata-rata panjang polong tanaman, rata-rata jumlah lokul tanaman, bobot benih tanaman, dan bobot 100 benih adalah rendah.
\end{abstract}

Kata Kunci : keragaan, keragaman, heritabilitas, kacang panjang, generasi $\mathrm{F}_{1}$

\section{PENDAHULUAN}

Indonesia merupakan sentra pertanaman kacang panjang yang mempunyai keanekaragaman genetik yang luas (Deanon dan Soriana 1967). Kacang panjang memiliki banyak kegunaan dan keunggulan. Kacang panjang termasuk sayuran yang banyak dikonsumsi di Indonesia. Kacang panjang memiliki kandungan gizi yang cukup lengkap (protein, lemak, karbohidrat, kalsium, fosfor, besi, vitamin B dan C). Kandungan protein nabati pada sayur kacang panjang berkisar 17-21\% (Kusmana, 2008).

Kebutuhan sayur-sayuran akan semakin meningkat seiring dengan semakin pedulinya masyarakat akan makanan yang sehat dan berimbang. Kacang panjang sebagai salah satu jenis dari sayursayuran dapat menjadi pilihan yang mudah untuk sebagian masyarakat. Hal ini dapat dilihat dari konsumsi kacang panjang pada tahun 2006 yang diperkirakan sebesar $2.66 \mathrm{~kg} / \mathrm{kapita} / \mathrm{tahun}$, yang berarti diperlukan kacang panjang sebanyak 492.000 ton/tahun (BPS 2007). Akan tetapi, berdasarkan data BPS (2007) produktivitas kacang panjang baru mencapai sekiar 354.000 ton/tahun. Berdasarkan hal tersebut perlu adanya penggunaan varietas unggul untuk meningkatkan produksi. Varietas unggul dapat diperoleh dari usaha pemuliaan tanaman melalui persilangan.

Persilangan menggunakan tiga genotipe kacang panjang, yaitu testa merah putih, testa hitam, dan testa coklat. Masing-masing genotipe memiliki karakter yang berbeda-beda. Kacang panjang testa merah putih memiliki karakter testa (kulit biji) berwarna merah dan putih, benih bernas, vigor bagus, adaptasi luas, panjang $80-100 \mathrm{~cm}$, buah lebat, dan bentuk polong yang panjang. Testa hitam memiliki karakter vigor bagus, buah lebat, polong renyah, warna hijau gelap, rasa manis, panjang polong 50-80 cm, dan tahan disimpan (Mahendra, 2010). Kacang panjang testa coklat memiliki keunggulan 
adaptasi yang luas, warna polong hijau terang, dan panjang polong sekitar 60-90 cm (Destyasari, 2009). Persilangan yang dilakukan menggunakan 3 genotipe akan menghasilkan generasi $\mathrm{F}_{1}$ yang beragam, sehingga terjadi suatu keragaman. (Setiamihardja 1993, Tenaya et al. 2001, Zijlstra et al. 1991).

Keragaman adalah perbedaan yang ditimbulkan dari suatu penampilan populasi tanaman. Keragaman genetik merupakan salah satu faktor yang sangat berpengaruh terhadap keberhasilan pemuliaan tanaman. Adanya keragaman genetik dalam suatu populasi berarti terdapat variasi nilai genotipe antar individu dalam populasi tersebut (Karmana dkk. 1990). Sumber keragaman genetik didapat dari introduksi, persilangan, mutasi, atau melalui proses transgenik. Hasil persilangan merupakan sumber keragaman yang umum dilakukan dibandingkan menciptakan sumber keragaman dengan cara lainnya. Keragaman menetukan efektifitas seleksi. Seleksi akan efektif apabila keragaman luas. Selain keragaman, heritabilitas juga menetukan efektifitas suatu seleksi. Heritabilitas merupakan suatu parameter genetik yang mengukur kemampuan suatu genotipe dalam populasi tanaman untuk mewariskan karakteristik-karakteristik yang dimiliki. Makin tinggi nilai heritabilitas suatu sifat maka makin besar pengaruh genetiknya dibanding lingkungan (Poespadorsono, 1988).

Berdasarkan tingkat keberhasilan persilangan antarvarietas kacang panjang maka perlu dilihat keragaan (performa) generasi keturunannya $\left(\mathrm{F}_{1}\right)$, sehingga dapat dilihat keragaan dan keragaman antarhasil persilangan. Selain keragaman perlu diperhatikan pula bagaimana karakter yang diamati diturunkan. Penurunan sifat dapat diketahui dengan nilai duga heritabilitas. Oleh karena itu, penelitian ini bertujuan untuk melihat keragaan, keragaman, dan nilai duga heritabilitas arti luas karakter agronomi generasi $F_{1}$ hasil persilangan tiga tetua yang berbeda.

\section{METODE PENELITIAN}

Penelitian ini dilaksanakan di kebun percobaan Fakultas Pertanian dan Laboratorium Benih dan
Pemuliaan Tanaman Fakultas Pertanian Universitas Lampung pada bulan November 2011 sampai bulan April 2012.

Benih yang digunakan adalah benih $\mathrm{F}_{1}$ kacang panjang yang merupakan hasil persilangan antara testa merah putih $\mathrm{x}$ testa hitam $(\mathrm{AxB})$, testa hitam $\mathrm{x}$ testa merah putih (BxA), testa hitam $x$ testa coklat $(\mathrm{BxC})$, testa coklat $x$ testa merah putih $(\mathrm{CxA})$, benih tetua testa merah putih, testa hitam, testa coklat. Pupuk yang digunakan adalah pupuk kompos, pupuk majemuk 4 gram/lubang, dan penyemprotan insektisida menggunakan insektisida Decis, insektisida Dithane M 45, dan insektisida Furadan 3G.

Perlakuan disusun dalam Rancangan Kelompok teracak Sempurna (RKTS), 3 ulangan. Masing-masing perlakukan diterapkan pada unit percobaan (plot) dengan ukuran $0,8 \mathrm{~m}$ x 1,5 m. Model linier aditif yang dipakai adalah :

$\mathrm{Xij}=\mu+\alpha \mathrm{i}+\beta j+\epsilon i j$

Keterangan :

$\mathrm{X}_{\mathrm{ij}} \quad=$ Setiap nilai pengamatan dari kelompok ke-i, varietas ke-j

$\mu=\quad=$ Nilai tengah populasi

$\alpha \bar{i} \quad=$ Pengaruh kelompok ke-i

$\beta_{j}^{j} \quad=$ Pengaruh varietas ke-j

$e_{i j}=$ Pengaruh galat percobaan pada kelompok

ke-i, varietas ke-j.

Untuk membandingkan keragaan genotipe hasil persilangan dengan tetua maka digunakan uji Least Significance Increase (LSI).

$$
\mathrm{LSI}=\mathrm{t}_{\alpha} \sqrt{\frac{2 K N T G}{N}}
$$

keterangan:

t $\alpha=$ Nilai tengan t-studen pada $\alpha$ pada derajad bebas dari KNTG pada eka arah

$\mathrm{n} \quad=$ Jumlah ulang genotipe yang diuji

KNTG $=$ Kuadrat nilai tengah galat .

Kemudian perbandingan antar genotipe diuji menggunakan kontrol untuk mengetahui apakah terdapat genotipe yang memiliki kualitas karakter lebih baik atau sama dengan kontrol. Apabila data genotipe yang diuji

Tabel 1. Model analisis ragam rancangan kelompok teracak sempurna

\begin{tabular}{cccccc}
\hline $\begin{array}{c}\text { Sumber } \\
\text { keragaman }\end{array}$ & $\begin{array}{c}\text { Derajat } \\
\text { bebas }\end{array}$ & $\begin{array}{c}\text { Jumlah } \\
\text { Kuadrat }\end{array}$ & $\begin{array}{c}\text { Kuadrat } \\
\text { tengah }\end{array}$ & $\begin{array}{c}\text { Kuadrat tengah } \\
\text { harapan }\end{array}$ & $\mathrm{F}_{\text {hit }}$ \\
\hline Kelompok & $\mathrm{r}-1$ & $\mathrm{~A}$ & $\mathrm{M}_{3}$ & & \\
Genotipe & $\mathrm{g}-1$ & $\mathrm{~B}$ & $\mathrm{M}_{2}$ & $\sigma_{\varepsilon}^{2}+\mathrm{r} \sigma_{g}^{2}$ & $\mathrm{M}_{2} / \mathrm{M}_{1}$ \\
Galat & $(\mathrm{r}-1)(\mathrm{g}-1)$ & $\mathrm{C}$ & $\mathrm{M}_{1}$ & $\sigma_{\varepsilon}^{2}$ & \\
\hline
\end{tabular}


lebih besar dibandingkan dengan data rata-rata tetua + nilai LSI nya menunjukan bahwa nilai genotipe yang diuji lebih tinggi dibandingkan tetuanya.

Berdasarkan analisis varians (ragam) dapat diduga ragam genetil $\left(\sigma_{g}^{2}\right)$ dan fenotipik $\left(\sigma_{t}^{2}\right)$ Menurut Singh dan Chaudary (1979), rumus yang digunakan untuk menduga nilai ragam, adalah sebagai berikut :

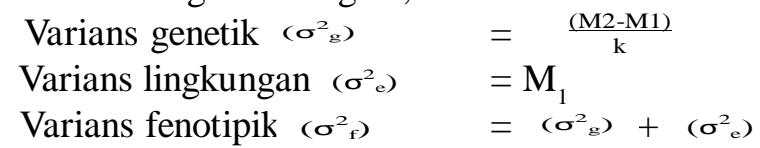

Untuk mengetahui apakah keragaman luas ataupun sempit dilakukan dengan cara membandingkan ragam dengan standar deviasinya (Anderson dan Bancroff, 1952 dikutip Wahdah, 1996). Apabila nilai ragam lebih besar dari dua kali standar deviasi maka dinyatakan karakter yang diuji memiliki keragamani yang luas.

Standar deviasi (SD) dihitung menggunakan:

$\begin{aligned} \text { SD genetik } & =\sqrt{\frac{2}{K^{2}}\left[\frac{M_{2}^{2}}{d k \text { genotipe }+2}+\frac{M_{1}^{2}}{d k \text { galat }+2}\right]} \\ \text { SD fenotipik } & =\sqrt{\frac{2}{K^{2}}\left[\frac{M_{1}^{2}}{d k \text { genotipe }+2}\right]}\end{aligned}$

Untuk menentukan nilai duga heritabilitas arti luas ditentukan dengan rumus: $\mathrm{H}=\frac{\sigma_{g}^{\frac{x}{g}}}{\sigma_{f}^{\frac{2}{x}}}$ (Suharsono dkk,

2006). Menurut Mc.Whiter kriteria nilai duga heritabilitas adalah sebagai berikut : heritabilitas tinggi apabila $\mathrm{H}>5$; heritabilitas sedang $0,2 \leq \mathrm{H} \leq 0,5$; heritabilitas rendah $\mathrm{H}<0,2$.

\section{HASIL DAN PEMBAHASAN}

Hasil analisis ragam menujukkan adanya perbedaan antara genotipe untuk peubah umur panen polong segar (UPPS), jumlah polong (JP), rata-rata jumlah lokul (RT JL) dan bobot benih (BB BNH) $(\mathrm{P} \leq$ $0,05)$ serta umur berbunga (UB), umur panen polong kering (UPPK), rata-rata jumlah polong (RT PPT), ratarata panjang lokul (RT PL), dan jumlah benih ( $\mathrm{J}$ BNH) $(\mathrm{P} \leq 0,1)$ (Tabel 2 dan 3).

Pada persilangan antara A x B hanya pada umur berbunga lebih lambat dibandingkan umur tetua $\mathrm{A}$, sedangkan apabila dibandingkan dengan tetua $\mathrm{B}$, umur berbunga, umur panen segar, umur panen kering lebih lambat. Dengan umur berbunga, umur panen segar, dan panen kering lebih lambat mengakibatkan rata-rata panjang polong menjadi lebih panjang (Tabel 4).

Pada persilangan antara $\mathrm{B} x \mathrm{~A}$, hanya umur panen polong segar yang lebih lambat bila dibandingkan dengan tetua A, sedangkan apabila dibandingkan dengan tetua $\mathrm{B}$, umur berbunga, umur panen segar, dan umur panen kering lebih lambat. Akibatnya rata-rata jumlah polong, jumlah biji per tanaman, dan bobot biji menjadi lebih banyak (Tabel 4). Pada persilangan antara $\mathrm{C} x \mathrm{~A}$, hanya

Tabel 2. Rekapitulasi nilai kuadrat tengah analisis ragam untuk karakter umur berbunga (UB), umur panen polong segar (UPPS), umur panen polong kering (UPPK), jumlah tangkai bunga (JTB), jumlah polong (JP), dan rata-rata jumlah polong (RT.JP)

\begin{tabular}{lllccccc}
\hline \multirow{2}{*}{$\begin{array}{c}\text { Sumber } \\
\text { keragaman }\end{array}$} & \multirow{2}{*}{$\mathrm{Db}$} & \multicolumn{7}{c}{ Kuadrat nilai tengah } \\
\cline { 2 - 7 } & & \multicolumn{1}{c}{ UB } & UPPS & UPPK & JTB & JP & RT.JP \\
\hline Variets & 6 & $59,21^{* *}$ & 106,49 & 143,98 & 14,29 & $975,71^{*}$ & $42,09 * *$ \\
Galat & 12 & 5,87 & 38,44 & 31,08 & 32,95 & 281,76 & 8,49 \\
\hline KK & & 2,98 & 5,41 & 4,53 & 15,31 & 17,48 & 17,48 \\
\hline
\end{tabular}

Keterangan * : Berbeda pada $\alpha_{0,05}, * *$ : Berbeda pada $\alpha_{0,01}$

Tabel 3. Rekapitulasi nilai kuadrat tengah analisis ragam untuk karakter rata-rata panjang polong tanaman (RT.PPT), rata-rata jumlah lokul (RT.JL), rata-rata panjang lokul (RT.PL), jumlah benih (J.BNH), bobot benih (BB.BNH), dan bobot 100 butir (100 BTR)

\begin{tabular}{lccclclc}
\hline \multirow{2}{*}{$\begin{array}{c}\text { Sumber } \\
\text { keragaman }\end{array}$} & Db & \multicolumn{7}{c}{ Kuadrat nilai tengah } \\
\cline { 3 - 7 } & & RT.PPT & RT.JL & RT.PL & J.BNH & BB.BNH & 100 BTR \\
\hline Variets & 6 & 61,29 & $49,72^{*}$ & $0,32 * *$ & $5562,32 * *$ & $95,87 *$ & 3,31 \\
Galat & 12 & 21,41 & 31,09 & 0,03 & 985,47 & 30,97 & 1,92 \\
\hline KK & & 2,98 & 5,41 & 4,38 & 32,23 & 28,59 & 3,42 \\
\hline
\end{tabular}

Keterangan $*$ : Berbeda pada $\alpha_{0,05}, * *$ : Berbeda pada $\alpha_{0,01}$ 
umur berbunga yang lebih lambat bila dibandingkan dengan tetua $\mathrm{A}$, sedangkan bila dibandingkan dengan tetua $\mathrm{C}$, umur berbunga, umur panen segar, dan umur panen kering lebih awal, demikian juga variabel yang lain lebih rendah bila dibandingkan dengan kedua tetuanya (Tabel 4).

Pada persilangan antara $\mathrm{B} \times \mathrm{C}$, umur berbunga, umur panen seger, dan umur panen kering melebihi tetua $\mathrm{B}$, sedangkan bila dibandingkan dengan tetua $\mathrm{C}$ umur tanaman lebih awal. Rata-rata jumlah lokul persilangan $\mathrm{B} \times \mathrm{C}$ melebih kedua tetuanya. Untuk bobot biji hasil persilangan $\mathrm{B} \times \mathrm{C}$ hanya melebih tetua $\mathrm{C}$ (Tabel 4).

Secara keseluruhan tetua $\mathrm{C}$ umurnya lebih awal. Bobot benih tetinggi didapat pada persilangan $\mathrm{B} \times \mathrm{A}$ dan B x C. Hal ini mungkin disebabkan oleh tetua B yang bobot benihnya tinggi. Bobot benih A x B sama dengan bobot benih tetua B (Tabel 4).

Pada umumnya ragam fenotipe memiliki keragaman yang luas pada karakter yang diamati, yaitu umur berbunga, umur panen polong segar, umur panen polong kering, jumlah tangkai bunga, jumlah polong tanaman, rata-rata jumlah polong tanaman, rata-ratarata panjang polong tanaman, rata-rata jumlah lokul tanaman, rata-rata panjang lokul, jumlah benih total, bobot benih, dan bobot 100 benih (Tabel 5). Nilai keragaman fenotipe yang luas pada semua variabel yang diamati dipengaruhi oleh genetik dan lingkungan.

Keragaman genotipe yang luas terdapat pada variabel umur berbunga, umur panen polong kering, jumlah polong tanaman, rata-rata jumlah polong tanaman, rata-rata panjang lokul, jumlah benih total, dan bobot benih tanaman (Tabel 6). Keragaman yang luas disebabkan karena benih yang digunakan adalah benih $\mathrm{F}_{1}$ yang masih heterozigot yang merupakan hasil persilangan tetua-tetua yang memiliki genotipe berbeda.

Terdapat keragaman genotipe yang sempit pada variabel umur panen polong segar, jumlah tangkai bunga, rata-rata panjang polong tanaman, rata-rata jumlah lokul tanaman, dan bobot 100 benih. Sempitnya keragaman genotipe yang diamati disebabkan oleh faktor genetik dari kedua tetuanya.

Varietas yang digunakan sebagai tetua dimungkinkan tidak memiliki perbedaan terhadap variabel tersebut. Keragaman genotipe yang sempit sedangkan keragaman fenotipe luas, hal ini diduga pengaruh faktor lingkungan yang tinggi atau faktor lingkungan yang berperan lebih besar daripada faktor genetiknya.

Tabel 4. Uji LSI beberapa karakter agronomi kacang panjang hasil persilangan dari tiga genotipe

\begin{tabular}{lllllllllllll}
\hline Varietas & UB & UPPS & UPPK & JT & JP & RT.JP & RT.PP & RT.JL & RT.PL & JBT & BB & 100 BTR \\
\hline AxB & 48,33 & 61,67 & 80,33 & 12,92 & 26,67 & 6,67 & 40,05 & 11,43 & 1,42 & 49,92 & 7,98 & 15,27 \\
BxA & 41,33 & 66,00 & 72,33 & 12,75 & 61,00 & 15,25 & 29,83 & 10,67 & 1,49 & 129,58 & 20,59 & 15,79 \\
A+Lsi & 42,85 & 61,09 & 83,79 & 22,88 & 64,43 & 9,95 & 44,39 & 18,44 & 1,86 & 176,59 & 15,11 & 15,58 \\
A x B & + & $=$ & - & - & - & - & - & - & - & - & - & $=$ \\
B x A & - & + & - & - & - & - & - & - & - & - & - & $=$ \\
B+Lsi & 37,52 & 53,42 & 65,79 & 23,21 & 80,1 & 14,03 & 35,95 & 16,49 & 1,69 & 117,16 & 19,39 & 17,421 \\
A x B & + & + & + & - & - & - & + & - & - & - & - & - \\
B x A & + & + & + & - & - & + & - & - & - & + & + & - \\
CxA & 45,33 & 58,00 & 71,67 & 15 & 16,67 & 4,17 & 35,39 & 8,96 & 2,18 & 22,42 & 3,79 & 15,46 \\
A+Lsi & 42,85 & 61,09 & 83,79 & 22,88 & 64,43 & 9,95 & 44,39 & 18,44 & 1,86 & 176,59 & 15,11 & 15,58 \\
C X A & + & - & - & - & - & - & - & - & - & - & - & $=$ \\
C+Lsi & 46,52 & 62,42 & 71,46 & 24,46 & 42,43 & 9,28 & 38,59 & 15,36 & 2,04 & 114,59 & 13,61 & 18,94 \\
C x A & - & - & $=$ & - & - & - & - & - & $=$ & - & - & - \\
BxC & 38,67 & 55,33 & 70,33 & 15,33 & 40,67 & 10,17 & 28,77 & 20,95 & 1,19 & 79,42 & 15,42 & 16,52 \\
B+Lsi & 37,52 & 53,42 & 65,79 & 23,21 & 80,1 & 14,03 & 35,95 & 16,49 & 1,69 & 117,16 & 19,39 & 17,421 \\
BxC & + & + & + & - & - & - & - & + & - & - & - & - \\
C+Lsi & 46,52 & 62,42 & 71,46 & 24,46 & 42,43 & 9,28 & 38,59 & 15,36 & 2,04 & 114,59 & 13,61 & 18,94 \\
BxC & - & - & - & - & - & + & - & + & - & - & + & - \\
\hline Ketran
\end{tabular}

Keterangan: Genotipe yang digunakan adalah persilangan antara testa merah putih $\mathrm{x}$ testa hitam $(\mathrm{AxB})$, testa hitam $\mathrm{x}$ testa merah putih $(\mathrm{BxA})$, testa hitam $\mathrm{x}$ testa coklat $(\mathrm{BxC})$, testa coklat $\mathrm{x}$ testa merah putih $(\mathrm{CxA})$, dan varietas tetua yang digunakan adalah testa merah putih (A), testa hitam (B), testa coklat (C). Tanda (-) menunjukkan lebih rendah dibandingkan tetua. Tanda (+) menunjukkan lebih tinggi dibandingkan tetua.Tanda (=) menunjukkan sama dengan tetua. 
Heritabilitas digunakan untuk mengetahui seberapa besar pengaruh faktor genetik pada tingkat keragaman suatu karakter. Poespodarsono (1988) menyatakan makin tingginya nilai heritabilitas suatu sifat makin besar pengaruh genetiknya dibanding lingkungan, dan menurut Hadiati dkk (2003) bahwa tingginya nilai duga heritabilitas menunjukkan pengaruh lingkungan terhadap pewarisan sifat sangat kecil sehingga seleksi lebih efektif dan efisien untuk dilakukan pada generasi awal. Variabel yang memiliki nilai duga heritabilitas tinggi terdapat pada variabel umur berbunga dan rata-rata jumlah polong tanaman (Tabel 7).

Rendahnya nilai duga heritabilitas rendah dapat disebabkan oleh adanya pengaruh lingkungan lebih besar daripada genetik sehingga seleksi menjadi kurang efektif. Variabel yang memiliki nilai duga heritabilitas rendah terdapat pada umur panen polong segar, jumlah tangkai bunga, rata-rata panjang polong tanaman, rata-rata jumlah lokul tanaman, bobot benih tanaman, dan bobot 100 benih (Tabel 7). Hambatan untuk kemajuan program pemuliaan tanaman disebabkan karena kecilnya keragaman genetik, besarnya pengaruh lingkungan terhadap fenotip, atau kombinasi keduanya. Akan sangat sukar untuk menentukan keberadaan jumlah atau tipe variabilitas genetik jika ekspresi fenotipe sangat dipengaruhi oleh faktor lingkungan (Welsh, 1991). Dengan demikian, karekter yang memiliki nilai duga heritabilitas rendah tidak bisa digunakan sebagai kriteria seleksi generasi awal, sesuai dengan pendapat Sharma (1994) yang dikutip oleh Suwardi (2002), menyatakan bahwa suatu karakter yang memiliki nilai heritabilitas rendah harus diseleksi pada generasi lanjut.

Tabel 5. Ragam dan kriteria keragaman fenotipe pada populasi $\mathrm{F}_{1}$ hasil persilangan

\begin{tabular}{lcccc}
\hline Karakter & $\sigma_{f}^{2}$ & SD Fenotipik & $\begin{array}{c}2 \times \text { XD } \\
\text { Fenotipik }\end{array}$ & Keterangan \\
\hline Umur berbunga & 17,78 & 0,32 & 0,64 & Luas \\
Umur panen polong segar & 61,13 & 2,08 & 4,16 & Luas \\
Umur panen polong kering & 68,71 & 1,68 & 3,36 & Luas \\
Jumlah tangkai bunga & 26,73 & 1,78 & 3,56 & Luas \\
Jumlah polong tanaman & 513,08 & 15,21 & 30,42 & Luas \\
Rata-rata jumlah polong tanaman & 19,69 & 0,46 & 0,92 & Luas \\
Rata-rata panjang polong tanaman & 34,71 & 1,16 & 2,32 & Luas \\
Rata-rata jumlah lokul tanaman & 37,31 & 1,68 & 3,36 & Luas \\
Rata-rata panjang lokul & 0,12 & 0,0015 & 0,003 & Luas \\
Jumlah benih total & 251,09 & 53,21 & 106,42 & Luas \\
Bobot benih tanaman & 52,6 & 1,67 & 3,34 & Luas \\
Bobot 100 benih & 2,38 & 0,1 & 0,2 & Luas \\
\hline
\end{tabular}

Tabel 6. Ragam dan kriteria keragaman genotipe pada populasi F1 hasil persilangan

\begin{tabular}{lcccl}
\hline Karakter & $\sigma_{g}^{2}$ & SD genetik & $\begin{array}{c}2 \times \text { SD } \\
\text { genetik }\end{array}$ & Keterangan \\
\hline Umur berbunga & 23,65 & 4,51 & 9,02 & Luas \\
Umur panen polong segar & 22,68 & 12,78 & 25,56 & Sempit \\
Umur panen polong kering & 37,63 & 13,22 & 26,44 & Luas \\
Jumlah tangkai bunga & $-6,22$ & 8,67 & 17,34 & Sempit \\
Jumlah polong tanaman & 231,32 & 102,61 & 205,22 & Luas \\
Rata-rata jumlah polong tanaman & 11,19 & 3,77 & 7,54 & Luas \\
Rata-rata panjang polong tanaman & 13,29 & 7,21 & 14,42 & Sempit \\
Rata-rata jumlah lokul tanaman & 6,21 & 9,04 & 18,08 & Sempit \\
Rata-rata panjang lokul & 0,097 & 0,024 & 0,048 & Luas \\
Jumlah benih total & 1525,62 & 53,21 & 106,42 & Luas \\
Bobot benih tanaman & 21,63 & 10,74 & 21,48 & Luas \\
Bobot 100 benih & 0,46 & 0,56 & 1,12 & Sempit \\
\hline
\end{tabular}


Tabel 7. Heritabilitas pada populasi hasil persilangan

\begin{tabular}{lcc}
\hline Karakter & Heritabilitas & Kesimpulan \\
\hline Umur berbunga & 0,57 & Tinggi \\
Umur panen polong segar & 0,14 & Rendah \\
Umur panen polong kering & 0,29 & Sedang \\
Jumlah tangkai bunga & 0,05 & Rendah \\
Jumlah polong tanaman & 0,20 & Sedang \\
Rata-rata jumlah polong tanaman & 0,32 & Sedang \\
Rata-rata panjang polong tanaman & 0,15 & Rendah \\
Rata-rata jumlah lokul tanaman & 0,03 & Rendah \\
Rata-rata panjang lokul & 0,61 & Tinggi \\
Jumlah benih total & 0,37 & Sedang \\
Bobot benih tanaman & 0,17 & Rendah \\
Bobot 100 benih & 0,04 & Rendah \\
\hline
\end{tabular}

\section{KESIMPULAN}

Kesimpulan yang dapat diambil dari penelitian ini bahwa generasi $\mathrm{F}_{1}$ kacang panjang hasil persilangan dari tetua Merah Putih, Hitam dan Coklat memiliki rata-rata lebih tinggi dibandingkan tetua, tidak pada seluruh karakter. Seluruh peubah yang diamati memiliki nilai keragaman fenotipe yang luas, sedangkan pada keragaman genotipenya memiliki nilai keragaman yang luas kecuali pada umur panen polong segar, jumlah tangkai bunga, rata-rata panjang polong tanaman, ratarata jumlah lokul, dan bobot 100 benih. Variabel yang memiliki nilai duga heritabilitas tinggi terdapat pada variabel umur berbunga dan rata-rata panjang lokul. Nilai duga heritabilitas sedang terdapat pada variabel umur panen polong kering, jumlah polong tanaman, rata-rata jumlah polong tanaman, dan jumlah benih total. Sedangkan variabel yang memiliki nilai duga heritabilitas rendah adalah umur panen polong segar, jumlah tangkai bunga, rata-rata panjang polong tanaman, rata-rata jumlah lokul tanaman, bobot benih tanaman, dan bobot 100 benih.

\section{DAFTAR PUSTAKA}

Deanon, J.R. and J.M. Soriana.1967. The legumes vegetales production in somas East Asia ch 6:6669.

Kumaunang, J., dan I. Maskromo. 2007. Keragaan Genetik Plasma Nutfah Kelapa Dalam (Cocos Nucifera L) di Kebun Percobaan Mapanget Berdasarkan Penanda DNA RSSr. Buletin Palma No.33.
Kusmana, Suherli. 2008. Keterbacaan Buku Teks Pelajaran. [Online]. Tersedia http:// suherlicentre.Blogspot.com/2008/07/ keterbacaan-buku-teks-pelajaran.html[22 November 2011]

Mc. Whirter, K.S.1979. Breeding of Cross Pollinated Crops. In R. Knight (ed) Plant Breeding. A. A. U.C.S., Brisbane.

Poespadorsono. S. 1998. Dasar-Dasar Pemuliaan Tanaman. PAU Institut Pertanian Bogor. Bogor.

Suwardi., S.Poerwoko, dan N.Basuki. 2002. Implikasi keragaman genetik korelasi fenotipik, dan genotipik untuk perbaikan hasil sejumlah galur kedelai (Glicyne max (L). Merrill). http:/ /images. Soemarno.multiply.com/attachement/0/ $\mathrm{R}$ f u r a Q o K C p k A A e $8 \mathrm{~S}$ a j U 1 / kedelai5.doc?nmid=22330493.

Soetiarso, T.A. dan L. Marpaung.1995. Preferensi konsumen rumah tangga terhadap kaulitas kacang panjang. J. Hort. 5(3):46-52.

Van Lieshout, O. 1992. Consumption of fresh vegetables in Indonesia, A forecast for required production area in 2000. Internal Communication LEWUATA 395 No.48. 35 p.

Wahdah, R. 1996. Variabilitas dan Pewarisan Laju Akumulasi Bahan Kering PadaBiji Kedelai , (Disertasi). Program Pasca Sarjana Universitas Padjadjaran. Bandung. $130 \mathrm{hlm}$.

Welsh, J.R. 1991. Dasar-Dasar Genetika dan Pemuliaan Tanaman. Diterjemahkan oleh Mogea, J.P. Penerbit Erlangga. Jakarta. 224 hlm. 